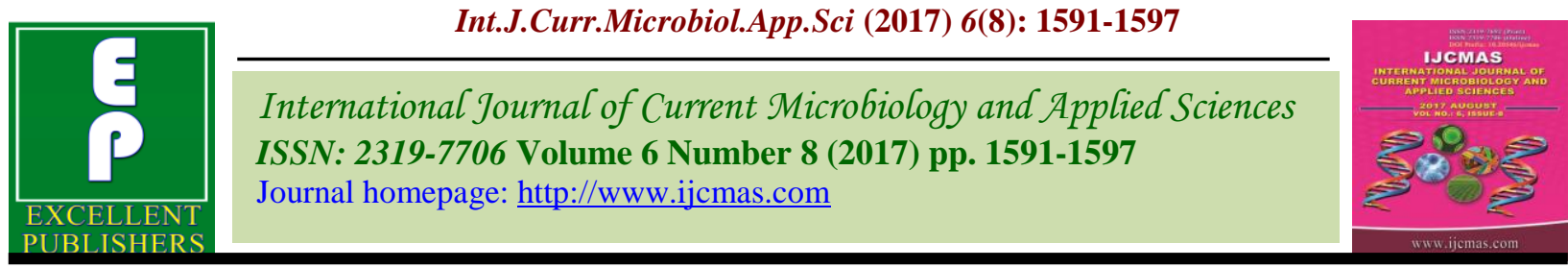

Original Research Article

https://doi.org/10.20546/ijcmas.2017.608.190

\title{
Prevalence, Serodiagnosis and Histopathological Changes in Field Cases of Infectious Bronchitis in Chickens
}

\author{
S. Gola ${ }^{1}$, S.K. Shukla ${ }^{1}$, S. Shekhar ${ }^{2}$ and Mahesh Kumar ${ }^{1}$ \\ ${ }^{1}$ Department of veterinary medicine, C.V.A.Sc., Pantnagar, G.B.P.U.A.T, Pantnagar-264145, \\ Uttarakhand, India \\ ${ }^{2}$ Krishi Vigyan Kendra (ICAR-NRRI-CRURRS), Jainagar-825109, Koderma, Jharkhand, India \\ *Corresponding author
}

A B S T R A C T

\begin{tabular}{|l|}
\hline Ke y w o r d s \\
Serodiagnosis, \\
Histopathological, \\
Field case, \\
Chickens. \\
\hline Article Info \\
\hline $\begin{array}{l}\text { Accepted: } \\
\text { 17 June 2017 } \\
\text { Available Online: } \\
\text { 10 August } 2017\end{array}$ \\
\hline
\end{tabular}

Infectious bronchitis (IB) is an acute highly contagious viral disease of respiratory and urogenital system of chickens affecting both broilers and layers. Present studies suggested that HA and HI tests are more superior, inexpensive, sensitive and rapid for identification of Infectious Bronchitis Virus (IBV) as compared to AGPT. The necropsy and histopathological examination indicated the involvement of nephropathogenic avian IBV.

\section{Introduction}

Infectious Bronchitis (IB) causes huge mortality, poor body weight gain in broilers and decreased egg production in layers. Infectious bronchitis virus (IBV) is prevalent in all countries with intensive poultry industries, with the incidence of infection approaching $100 \%$ in most locations. All IBV types can be isolated from upper respiratory tract, with highest concentration found in the trachea during 3 to 5 days post-infection. After this period, virus titer fall quickly in the second week, below the detection levels (De Wit, 2000). In younger chick affected with IB, nephritis, mortality up to $25 \%$ is common (Cumming, 1996; Meulemans et al., 1987). IB is clinically characterized by respiratory rales, coughing and sneezing (Chandranaik et al., 2005). Some IBV strains replicate in gastrointestinal tract, oviduct and kidneys due to their nepropathogenic properties, they have potential to cause up to $44 \%$ mortality (Cavanagh, 2005).

In other cases infection of proventiculus leads to 75 to $100 \%$ mortality in young birds (Yu et al., 2001). Diagnosis of IBV is confirmed by isolation of the virus using either chick embryonated egg (ECE) or tracheal organ culture (TOC) and detection by reverse transcriptase polymerase chain reaction (RTPCR) (Cavanagh and Naqi, 2003). The necropsy and histopathological examination are indicated to confirm the involvement of nephropathogenic avian IBV. 


\section{Materials and Methods}

Prevalence of infectious bronchitis was studied in total 10 commercial poultry farms were screened from August 2011 to December 2012. Udham Singh Nagar district of Kumaon division of Uttarakhand, India. The climate in district varies from subtropical and sub-humid with hottest months in May and June. The maximum temperature goes up to $42^{\circ} \mathrm{C}$ during summers and the minimum temperature is between 1 and $4^{\circ} \mathrm{C}$.

The average annual rainfall is $1296.85 \mathrm{~mm}$, about $90 \%$ of the rainfall occurring during the monsoon period, and the remaining $10 \%$ of the rainfall in non-monsoon period. These farms had history of mortality at early age, clinical signs like respiratory, renal and reproductive dysfunction, history of vaccination were noticed. Dead birds (carcasses) were collected in sterilized polythene bags, properly labeled and brought to laboratory and kept in refrigerator at $4^{\circ} \mathrm{C}$ until further used. On Post-mortem examination, gross pathological lesions (serous exudates and haemorrhage in trachea, air sacculitis, visceral and articulate gout) were noted. The tissue samples of lungs, trachea, kidney and cloacal swab were collected.

These organs were washed in normal saline and preserved in 50\% glycerol saline until the virus isolation was done (Jose et al., 2000). The tissues samples were thoroughly washed in HBBS (Hank's Balanced Salt Solution) homogenized in HBBS @ 10\% w/v, supplemented with penicillin@ $1000 \mathrm{IU} / \mathrm{ml}$ and streptomycin@1mg/ml in sterile pestle mortar with sterile sand. Tissue suspension was freezed and thawed twice, subsequently centrifuge in refrigerated centrifuged at 4000 rpm for 20 minutes. Supernatant was filtered with $0.22 \mu \mathrm{m}$ syringe filter kept at $-20^{\circ} \mathrm{C}$ until used (Jose et al., 2000). Supernatant fluid @
$0.2 \mathrm{ml}$ per egg was inoculated via intra allantoic route in 10 days old chicken's embryonated eggs. Eggs were incubated at $37^{\circ} \mathrm{C}$ and checked twice in a day according to method described by Gelb and Jackwood (1998). Embryo that died within 24 hrs after inoculation was discarded. Mortality of embryos occurs between 2 to 7 days post inoculation and it was considered to virus specific. Eggs were removed from the incubator 3-7 days post inoculation, and placed at $4^{\circ} \mathrm{C}$ for $24 \mathrm{hrs}$ and allantoic fluid of the embryos was collected aseptically for next passage.

Harvested fluid was five times blindly passaged in chicken embroynated eggs prior to being considered negative for IBV isolation (Gelb and Jackwood, 1998). Virus concentration was done with polyethylene glycol-6000 (PEG-6000) (Lohr, 1976). Agrose $1 \%$ was prepared in $0.9 \%$ normal saline and 5-10 $\mathrm{ml}$ of agrose was poured on a slide. Well of $3 \mathrm{~mm}$ diameter were punched at distance of 2-4 $\mathrm{mm}$ after solidification of agar. Wells were sealed with $1 \%$ agrose.

The wells were filled with antigen and known specific antibody against infectious bronchitis virus. Slide was incubated at $37^{\circ} \mathrm{C}$ for $24-72$ hrs, after incubation, kept the slide at $4^{\circ} \mathrm{C}$, if needed. The red precipitation line in light source against the dark back ground was noticed (Witter, 1962). HA and HI were conducted as per method described by (Mahmood et al., 2004a and Alexander et al., 1983). The trachea, liver, kidneys and lungs were removed and examined for any type of macroscopic alteration. The tissue samples were fixed in 10\% buffer formalin and serially dehydrated in alcohol and xyelene and embedded in paraffin blocks. The tissues were cut in 4-5 $\mu \mathrm{m}$ thick sections and stained in haematoxylin and eosin stain and examined for histopathological changes (Bancraft et al., 1990). 


\section{Results and Discussion}

Total of 10 positive poultry farms were identified during this study period. All cases were found positive for nephropathic from of infectious bronchitis showing both respiratory and renal disturbances. Nine broiler flocks, aged up to four weeks and one layer flock was found positive flocks during this time period. The clinical signs like dullness, depression, coughing, sneezing, hurdling, occulonasal discharge, tracheal rales, wet eye, gasping and gout etc. were recorded in the flocks. Butcher et al., (1990), Kinde (1991) and Mahgoub et al., (2010) also with recorded similar clinical findings. The mortality ranged from 5.4 to $35.2 \%$ with average mortality of $12.2 \%$ were recorded (Table 1). Hofstad (1998) recorded mortality up to 25 percent in young chick and Gaba et al., (2010) observed mortality up to $30 \%$ which are in agreement to the findings of the present study. The necropsy revealed serous exudates and haemorrhage in trachea. Visceral and articular gout with swollen, pale and inflamed kidneys indicated the involvement of nephropathogenic avian IBV. Similar findings were reported by $\mathrm{Ni}$ et $a l$., (2005). IBV was isolated in chicken embryos inoculated with tissues samples from all infected cases. Out of 10 samples, 7 samples showed embryonic changes. In first and second passage, none of the sample showed any lesion in embryos. After third passage stunting, mild curling, cutaneous haemorrhage and thickened chorioallantoic membrane but absence of renal damage and very less embryo mortality occurred. These changes are in accordance to the findings of Susan et al., (2010) except embryonic mortality and renal damage. They revealed the ability of the isolates to cause mortalities of SPF embryos by third passage after $72 \mathrm{hrs}$ post-inoculation and stunted growth with severe renal damage and deposition of urates within the ureters and urinary bladder. $\mathrm{Hu}$ et al., (1996) also recorded comparable result of stunted growth and death in IBV inoculated embryos after two or five serial passage. Very less embryo mortality in present study indicated that all field IBV strain were mildly pathogenic. The harvested embryo did not show the lesion of uriolethiasis, which could be due to the fact that all IBV are not nephropathogenic or all nephropathogenic difference IB isolates need not to induce renal damage in embryo due to strain (Wang et al., 1996). HA, HI and AGPT were conducted to identify the virus. Of total 10 samples, 6 samples were positive for AGPT with standard IBV antiserum. The result of AGPT was in accordance to Chandramohan et al., (1995). For HA test, none of sample directly agglutinated the chicken RBCs but treatment of virus with $2 \%$ trypsin induced the HA activity of virus. The result of HA test was clearly and consistent and seen within 35 min for $\mathrm{HI}$ test, $4 \mathrm{HA}$ unit virus was used. All samples were found positive for IBV through $\mathrm{HA}$ and HI tests. Positive HI test with the known specific antiserum of IBV confirmed that these samples were having infectious bronchitis virus. Chen et al., (1997) also found induced HA activity after treatment with $1 \%$ trypsin. These results were closely comparable with the findings of Mahmood et al., (2004a). They revealed HA activity of IBV within 5-10 min after treatment of $2 \%$ trypsin and concludes that trypsin induce HA (92\% sensitivity) is superior to AGPT (76\% sensitivity). Mahmood et al., (2004b) also detected the IBV through trypsin induced haemagglutination test (THA) showed 28 $100 \%$ sensitivity test. Present study also indicated that $\mathrm{HA}$ and $\mathrm{HI}$ tests are more superior, inexpensive, sensitive and rapid as compared to AGPT. Similar findings were also reported by De Wit et al., (1997) and De Wit (2000). The infectious bronchitis virus contains $\alpha$ 2, 3 linked nuraminic acid which hinder the HA activity (Schultze et al., 1992). HA activity can be induced by treating the virus suspension with phospholipase-c and 
neuraminidase enzymes. But use of trypsin induce HA activity is efficient, economic and sensitive (Cobro and Cunningham, 1959). Trachea of affected birds on histopathological examination revealed deciliation, desquamation of epithelial cells and serous exudation. Trachea of some birds showed haemorrhage. Lungs showed congestion, severe bronchopneumonia and infiltration of inflammatory cells. Kidney revealed tubular necrosis, hyaline degeneration, desquamation of epithelial cells, congestion, infiltration of inflammatory cell and deposition of urate crystal crystal surrounded by inflammatory cell. Microscopic examination of liver revealed mild to moderate degeneration and necrosis of hepatocytes, congestion, infiltration of inflammatory cells and dilatation of sinusoidal space and distortion of hepatic cord.

Table.1 Epidemiology of field cases of infectious bronchitis recorded from Aug. 2011 to May 2012

\begin{tabular}{|l|l|l|l|l|l|l|l|}
\hline $\begin{array}{l}\text { Sl. } \\
\text { no. }\end{array}$ & \multicolumn{1}{|c|}{$\begin{array}{c}\text { Code and place of poultry } \\
\text { farm }\end{array}$} & Strength & $\begin{array}{l}\text { Type } \\
\text { of } \\
\text { birds }\end{array}$ & $\begin{array}{l}\text { Age } \\
\text { Day }\end{array}$ & $\begin{array}{l}\text { System } \\
\text { affected }\end{array}$ & $\begin{array}{l}\text { Dead } \\
\text { birds }\end{array}$ & $\begin{array}{l}\text { Mortality } \\
(\%)\end{array}$ \\
\hline 1. & CPF,Kamary, Rampur & 2200 & Broiler & 8 & $\begin{array}{l}\text { Respiratory } \\
\text { and renal }\end{array}$ & 207 & 9.4 \\
\hline 2. & CJPF,Haldwani,Nainital & 2500 & Broiler & 23 & $\begin{array}{l}\text { Respiratory } \\
\text { and renal }\end{array}$ & 135 & 5.4 \\
\hline 3. & CPF,Ramnagar, Nainital & 1600 & Broiler & 6 & $\begin{array}{l}\text { Respiratory } \\
\text { and renal }\end{array}$ & 127 & 7.9 \\
\hline 4. & CPF,Shantipur,U.S.Nagar & 2000 & Broiler & 16 & $\begin{array}{l}\text { Respiratory } \\
\text { and renal }\end{array}$ & 174 & 8.7 \\
\hline 5. & CPF,Kamary, Rampur & 1500 & Broiler & 24 & $\begin{array}{l}\text { Respiratory } \\
\text { and renal }\end{array}$ & 177 & 11.8 \\
\hline 6. & CSPF,Kashipur, U.S.Nagar & 4000 & Layer & 12 & $\begin{array}{l}\text { Respiratory } \\
\text { and renal }\end{array}$ & 1408 & 35.2 \\
\hline 7. & CSRPF,Bajpur, U.S.Nagar & 3000 & Broiler & 7 & $\begin{array}{l}\text { Respiratory } \\
\text { and renal }\end{array}$ & 416 & 13.86 \\
\hline 8. & CPF,Kamary, Rampur & 3500 & Broiler & 6 & $\begin{array}{l}\text { Respiratory } \\
\text { and renal }\end{array}$ & 373 & 10.66 \\
\hline 9. & CPF,Bajwalpur,Nainital & 2500 & Broiler & 5 & $\begin{array}{l}\text { Respiratory } \\
\text { and renal }\end{array}$ & 304 & 12.1 \\
\hline 10 & CPF,Dhabni,Rampur & 2000 & Broiler & 6 & $\begin{array}{l}\text { Respiratory } \\
\text { and renal }\end{array}$ & 144 & 7.2 \\
\hline
\end{tabular}

The mucosa of the trachea in chickens infected with IB virus was edematous. There were losses of cilia, rounding and sloughing of epithelial cells, and minor infiltration of heterophils and lymphocytes within $18 \mathrm{hrs}$ of infection. If air sac involvement occurs, there is edema, epithelial cell desquamation, and some fibrinous exudates within $24 \mathrm{hrs}$ (Riddell, 1987). Janse et al., (1994) also reported the comparable findings like deciliation, sqamous metaplasia, cellular infiltration, edema of mucous and exudates as noticed by other workers (Butcher et al., 1990; Mahdavi et al., 2007). The virus replicates in ciliated epithelial cells causing deciliation, odema, desquamation, hyperplasia and mononuclear cell infiltration. The virus cause granular degeneration, vacuolation and desquamation of tubular epithelium, and massive infilteration of heterophils in interstitium in acute stage of disease. The lesions in tubules are most prominent in 
medulla. In urolithiasis, the urates associated with atrophied kidneys are distended with urates and often contains large caliculi composed of mainly of urates (Janse et al., 1994; Ziegler et al., 2002). These result also made an agreements of present findings.

Infectious bronchitis is an acute highly contagious viral disease of respiratory and urogenital system of chickens affecting both broilers and layers. During the study period between Aug. 2011 to May 2012, 10 poultry farm (9 broiler flocks, and 1layer flock) aged up to four weeks were found positive for infectious bronchitis. The mortality ranged from 5.4 to $35.2 \%$ with average mortality $12.2 \%$. The necropsy revealed serous exudates and haemorrhage in trachea, visceral and articular gout with swollen, pale and inflamed kidneys. HA and HI tests were found to be more superior, less expensive, sensitive and rapid for identification of Infectious Bronchitis Virus (IBV) as compared to AGPT. On histopathological examination, trachea of affected bird revealed deciliation, desquamation of epithelial cells and serous exudates. Lungs showed congestion, severe bronchopneumonia and infiltration of mononuclear cells. Kidney revealed tubular necrosis, hyaline degeneration and desquamation of epithelial cell, congestion and deposition of urate crystal. There was mild to moderate degree of nephritis. Liver showed mild to moderate degeneration and necrosis of hepatocytes, congestion, infiltration of inflammatory cells and dilatation of sinusoidal space and distortion of hepatic cord. The necropsy findings and histopathological examination indicated the involvement of nephropathogenic avian IBV.

\section{References}

Alexander, D. J., Allan, W. H. Biggs, P. M., Bracewell, C. D., Darbyshire, J. H.,
Dawson, P. S., Harris, A. H., Jordan, F. T. W., Macherson, I., Mcferran, J. B., Randall, C. J., Staurt, J. C. Swarbrick, O. and Wilding,G. P.1983. A standard technique for hamagglutination inhibition test for Infectious bronchitis virus. Avian Pathol. 5: 125-134.

Bancraft, J. D., Stevens, A. and Turner, D. R. (1990) Theory and practice of histological techniques. $3^{\text {rd }}$ edn. Churchill Livingstone. London, UK. pp.726

Butcher, G.D., Winterfield, R. W. and Shapiro, D. P. (1990).Pathogenesis of H13 nepropathogenic infectious bronchitis in commercial broiler. Avian Dis. 34(2): 916-921.

Cavanagh, D. (2005). Corona viruses in poultry and other birds. Avian Pathol. 34:439-448.

Cavanagh, D. and Naqi, S. A. (2003). Infectous Bronchitis. In: Calnek, B. W., Barenes, J. H., Beard, C. W. Mcdougald, L. R. and Saif, Y. M.(Eds). Disease of poultry. $10^{\text {th }}$ edn. Lowa State University Press, Ames. pp. 117-135.

Chandramohan, A., Shankar, V. K., Shaw, A. M., Chanran, N. D. J. and Nachimuthu, K. 1995. Comparison of different diagnostic test in detection of avian infectious bronchitis virus from experimentally induced chickens. Ind. J. Virol. 11(1): 43-46.

Chandranaik, B. M., Santosh, S. R., S. R. Sridhar, B. Y., Mayanna, A., Gomes, A. R., Harish, B. R., Mamtha, G. S., Jayakumar, S. R. and Krishnappa, G. (2005). Isolation of Infectious Bronchitis Virus from an outbreak in parent layer stock. Int. J. Poult. Sci. 4(8):584-585.

Chen, C. H., Shao, C. L. and Peng, D. X. 1997. Isolation and characterization of kidney type strain of infectious bronchitis virus. Chin. J. Vet. Sci. Technol. 27(3): 22-23. 
Cobro, L. J. and Cunningham, C. H. 1959.Haemagglutination by trypsin modified Infectious bronchitis virus. Am. J. Vet. Res. 20: 876-883.

Cumming, R. B. (1996).Studies on avian infectious bronchitis virus.1. Distribution and survival of virus in tissues affected chickens and studies on the carrier status. Aust. Vet.J.45:305308.

De Wit J. J., Mekkes, D. R., Kouwenhoven, B. and Verhei, J. H. M. 1997. Sensitivity and specificity of serological tests for Infectious Bronchitis virus antibodies in broilers. Avian Pathol. 26: $105-118$.

De Wit, J. J. (2000). Detection of Infectious Bronchitis Virus, Technical review. Avian, Pathol. 29: 71-93.

Gaba, A., Dave, H., Pal, J. K. and Prajapati, K. S. (2010).Isolation and identification and molecular characterization of IBV variant from an outbreak of visceral gout in commercial broilers. Vet.World 3 (8):375-377.

Gelb, J. and Jackwood, M. W. 1998. Infectous Bronchitis. In: Swayne, D. E., Glisson, J. R., Jackwood, M. W. Pearson, J. E. and Reid, W. M.(eds). A laboratory Manual for Isolation and Identification of AvianPathogens. $4^{\text {th }}$ edn. pp.169-174.

Hofstad, M. S. (1984). Avian infectious bronchitis In: Hofstad, M. S., Barnes, H. J., Calnek, B. W., Reid, M. W. and Yoder, H. W. (eds.) Disease of poultry. $8^{\text {th }}$ edn. Lowa state University Press: Ames. pp. 429-443.

Hu, J. H., Xie, X. Y., Zhang, Y. M. and Jin, P. F.1996. The isolation and identification of avian Infectious Bronchitis Virusnphrosis. J. Sanghai Agric.College. 14:122-126.

Janse, E. M., Roozelaar, D. V. and Koch, G. (1994).Leukocyte subpopulations in kidney and trachea of chickens infected with infectious bronchitis virus. Avian Pathol.23:513-523.

Jose, D. F., Lavinia, I. Rossini, S. J. Orbell, G. P., Micheal, B., Hugggins, A. M., Byron, G. M. Silva and cook, J. K. 2000.Characterization of Infectious Bronchitis viruses isolated from outbreaks of disease in commercial flocks in Brazil. Avian Dis. 44: 582589.

Kinde, H., Draft, B. M., Castro, A.E., Bickford, A. A., Gleb, J. and Reynolds, B. (1991).Viral pathogenesis of nephrotropic of infectious bronchitis virus isolated from commercial pullets. Avian Dis. 46(4) 938-944.

Lohr, J. E. 1976. Infectous bronchitis agar gel precipitation test-using infected allantoic fluid as an antigen. Avian Dis.24: 2.

Mahdavi, S., Tavasoly, A., Pourbakshsh, S. A. and Momayez, R. (2007).Experimental histopathologic study of the lesions induced by serotype 793/B (4/91) infectious bronchitis virus. Arch. Razi. Ins. 62 (2)15-22.

Mahgoub, K. M., Bassiouni, A. A., Afify, M. A. and Rabie, N. S. (2010). The prevalence of infectious bronchitis outbreaks in some chicken farms. I. Spotlight on the status of IB out breaks in some chicken flocks. J. Am. Sci. 6 (9):57-60.

Mahmood, M. S., Siddique, M. and Hussain, I. 2004a. Carrier state studies of Infectous bronchitis virus in asymptomatic Layer in Pakistan. Int. $J$. Poult. Sci. 3 (8): 547-549.

Mahmood, M. S., Siddique, M. and Hussain, I. and Khan, A. 2004b.Trypsin -induced haemagglutination assay for detection of Infectious bronchitis virus. Pak. Vet. J. 24 (2): 54-58.

Meulemans, G. Carlier, M. C., Gonze, M., Petit, P. and Vendenbroeck, M. (1987). Incidence, Characterization and 
prophylaxis of nephropathogenuc avian infectious bronchitis virus. Vet. Ree. 120:205-206.

Ni, B., Zhang, Y. M., Sun, P., Wang, J.Y., Mu, Y., Zhang, Y.G., Wei, Z. F., Wei, Z.F. and $\mathrm{Xu}, \mathrm{H}$. (2005). Isolation and identification of kidney strin of avian infectious bronchitis virus. Chin.J.Vet.Sci.Technol. 35:377-380.

Riddell, C. (1987). Avian histopathology. Am. Asso. Of Avian Path.: Kennet Squar, P.A.

Schultze, B., Cavanagh, D. and Herrrler, G. 1992. Neuraminidase treatment of Infectious bronchitis virus Corona virus reveals a haemagglutination activity that depends on sialic acid containing receptors on erythrocytes. Virol. 30 (1):183-189.

Susan, S., Elmahdy, M.M and Soliman, Y. A. (2010).Isolation and characterization of nephropathogenic strain of infectious bronchitis virus in Egypt. J. Am. Sci. 6(9):669-675.
Wang, C. H., Hsiesh, M. C. and Chang, P. C. 1996. Isolation, pathogenicity and $\mathrm{H} 120$ protection efficacy of Infectious bronchitis viruses isolated in Japan. Avian Dis. 41(2): 279-282.

Witter, R. L. 1962. The diagnosis of Infectious bronchitis of chicken by agar gel precipitation test. Avian Dis. 6: 478492.

Yu, L., Jiang, Y., Low, S., Wang, Z., Nam, S. J. Liu, W. and Kwang, J. (2001).Characterization of three infectious bronchitis virus isolates from china associated with proventiculus in vaccinated chickens. Avian Dise.45:416-424.

Ziegler, A. F., Ladman, B. S., Dunn, P. A., Schneider, A., Davison, S., Miller, P. G., Lu, H., Weinstock, D., Salem, M., Eckroade, R. J. and Gelb, J. (2002). Nepropathogenic Infectious Bronchitis in Pennsylvania chickens, 1997 2000.Avian Dis. 46(4)847-858.

\section{How to cite this article:}

Gola, S., S.K. Shukla, S. Shekhar and Mahesh Kumar. 2017. Prevalence, Serodiagnosis and Histopathological Changes in Field Cases of Infectious Bronchitis in Chickens. Int.J.Curr.Microbiol.App.Sci. 6(8): 1591-1597. doi: https://doi.org/10.20546/ijcmas.2017.608.190 